\title{
O Penhor no Direito Autoral Luso-brasileiro
}

The Pledge Copyright in Luso-Brazilian

Helenara Braga Avancini ${ }^{1}$

\section{RESUMO}

As garantias reais e pessoais constituem elementos importantes para o cumprimento das obrigações contraídas pelas partes. No entanto, pouco se fala sobre a possibilidade da utilização da propriedade intelectual como objeto de garantia, em especial, no que diz respeito ao Direito Autoral. Pretende o presente trabalho analisar como o direito português e brasileiro abordam o tema do penhor do Direito Autoral.

Palavras-Chave: Penhor, Garantias, Direito Autoral, Direito Comparado, Propriedade Intelectual.

\begin{abstract}
The real and personal guarantees are important elements for the fulfillment of obligations by the parties. However, little is said about the possibility of the use of intellectual property as object, in particular with regard to Copyright. This work aims to analyze how the Portuguese and Brazilian law address the issue of the pledge of the Copyright Law.
\end{abstract}

Keywords: Pledge, Guarantees, Copyright Law, Comparative Law, Intellectual Property.

\section{INTRODUÇÃO}

O Direito Autoral tem tratamento especial nos diversos ordenamentos jurídicos no mundo, não sendo diferente a abordagem dada pela Lei brasileira e portuguesa. As características deste Instituto fazem com que ele apresente peculiaridades que vão desde sua inserção dentro do Direito Civil até a possibilidade de utilização de determinadas regras e princípios obrigacionais e reais para a solução de lacunas apresentadas pela lei ou pela interpretação do contrato de natureza autoral.

Neste ponto, reside a necessidade de identificar o problema da possibilidade ou não de se atribuir garantias com as criações protegidas pelo Direito Autoral. Existe também, um fator

\footnotetext{
${ }^{1}$ Bolsista da CAPES - Proc. nº 3109/12-7 (Pós-Doutorado na Faculdade de Direito da Universidade de Lisboa). PIDCC, Aracaju, Ano II, Edição no 02/2013, p.01 a 24 Fev/2013 | www.pidcc.com.br
} 
importante a ser observado no tema, que é a questão da existência de um único direito que apresenta um viés duplo, um de ordem pessoal ou moral e outro de ordem patrimonial ou econômico. E é sobre as prerrogativas patrimoniais que as questões atinentes as garantias pode atingir, eis que o Direito Autoral pode ser visto, sob o ponto de vista econômico como um ativo intangível onde o titular de direito tem o grande interesse de sua exploração econômica.

Tradicionalmente as garantias podem ser pessoais e reais ${ }^{2}$, porém existem garantias pessoais típicas, tais como a fiança, o aval e garantias reais típicas, como a hipoteca, o penhor, apenas para citar alguns exemplos.

Ao se utilizar a expressão típica, está se dizendo que em contraposição existem as atípicas que igualmente apresentam a mesma função de garantir um negócio jurídico. As típicas estão previstas dentro do Código Civil, e são utilizadas de acordo com o cumprimento ou preenchimento dos requisitos impostos pela lei. As atípicas embora exerçam uma função de garantia estão, por vezes "disfarçadas" em outro negócio jurídico, e. g. em um contrato, que vai ter o mesmo objetivo que um penhor, uma hipoteca, uma fiança, etc.

Conforme destaca António Menezes Cordeiro, as "garantias reais ou direitos reais de garantia são permissões normativas de aproveitamento de coisas corpóreas, em termos de assegurar direitos de crédito". 3 No Código Civil Português encontram-se tipificadas as seguintes garantias reais típicas: a consignação de rendimentos, o penhor, a hipoteca, os privilégios creditórios e o direito de retenção. ${ }^{4}$

No Brasil, o Código Civil, no artigo 1.225, considera como Direitos Reais algumas garantias como é o caso do penhor, da hipoteca, da anticrese, porém, a exemplo do que ocorre no ordenamento jurídico, encontram-se outras garantias reais neste diploma legal, mas que não foram incluídas no rol do artigo citado, muito embora sejam direitos reais por se tratar de propriedade, é o caso da propriedade fiduciária e a reserva de domínio ou de propriedade. $^{5}$

\section{1 - Penhor}

\footnotetext{
${ }^{2}$ Luís Manuel Teles de Menezes Leitão apresenta classificação mais detalhada, pois parte das garantia geral para as especiais e, dentro destas, subdivide-as em pessoais, reais, sobre direitos, sobre universalidades e atípicas. LEITÃO, Luís Manuel Teles de Menezes. Garantia das obrigações. $3^{\mathrm{a}}$ ed. Coimbra: Almedina, 2012, p. 20 22.

${ }^{3}$ MENEZES CORDEIRO, António. Tratado de Direito Civil Português, $2^{\circ}$ v.: Direito das Obrigações, $4^{\circ}$ t.: cumprimento e não cumprimento, transmissão, modificação e extinção, garantias. Coimbra:Almedina, 2010 , p. 543.

${ }^{4}$ Idem, ibidem.

${ }^{5}$ Artigo 1.225. São direitos reais:I - a propriedade; II - a superfície;III - as servidões; IV - o usufruto; V - o uso; VI - a habitação; VII - o direito do promitente comprador do imóvel; VIII - o penhor; IX - a hipoteca; X - a anticrese. XI - a concessão de uso especial para fins de moradia; XII - a concessão de direito real de uso.
} 
É oportuno observar que a palavra "penhor" apresenta significados diversos sob o ponto de vista coloquial e jurídico. Assim é que a palavra penhor apresenta diversos significados, pois como destaca Antunes Varela

a palavra penhor é usada, quer na linguagem corrente, quer no vocabulário técnico dos juristas, num tríplice sentido. Penhor é o direito de preferência conferido ao credor, tal como o artigo $666 .^{\circ}$ o descreve; mas penhor é também a coisa (móvel) dada como garantia (loja de penhores, leilão de penhores, venda judicial do penhor, etc.); e penhor se chama ainda ao contrato que serve de fonte ao direito especial de garantia conferido ao credor. $^{6}$

Esta visão tríplice também é apontada por António Menezes Cordeiro, apoiado em Luigi Lordi, segundo o qual a expressão designa "um direito real de garantia, o objecto desse direito real e o contrato fonte desse direito real". 7

Para o presente estudo, interessa vê-lo como um direito real de garantia, situação em que "o penhor traduz a afectação jurídica de uma coisa corpórea móvel, em termos de satisfação de determinado direito de crédito" ${ }^{8}$, conforme refere o mesmo autor.

Observe que o conceito dado pelo ilustre professor luso se refere a "coisa corpórea móvel", portanto não inclui a coisa incorpórea dentro do direito real de garantia (penhor), o que acaba por refletir na indagação feita pelo mesmo: "pergunta-se se não haverá aqui uma hipótese de direito real sobre coisas incorpóreas, ou, mais latamente, de direito sobre direito". 9

Tanto é assim que Luís Manuel Menezes Leitão destaca uma categoria específica, qual seja a das garantias especiais sobre direitos, onde "não ocorre a afectação de uma coisa em termos reais, mas antes de um direito de outra natureza, que pode inclusivamente ser um crédito, sendo esta uma situação distinta das garantias pessoais, uma vez que é o titular do direito que o oferece em garantia, não ocorrendo uma nova vinculação". 10

Vê-se que o autor afasta este espécie de penhor das garantias reais, porque parte do estudo do penhor de créditos que é o mais comum dentre os penhores de direitos, tendo em vista "não existir no penhor de créditos qualquer garantia real". ${ }^{11}$

\footnotetext{
${ }^{6}$ Idem, p. 520.

${ }^{7}$ Direitos Reais, p. 741.

${ }^{8}$ Idem.

${ }^{9}$ Direitos Reais, p. 753.

${ }^{10}$ Garantia das obrigações. $3^{\mathrm{a}}$ ed. Coimbra: Almedina, 2012, p. 21.

${ }^{11}$ Luís Manuel Teles de Menezes Leitão apresenta classificação mais detalhada, pois parte das garantia geral para as especiais e, dentro destas, subdivide-as em pessoais, reais, sobre direitos, sobre universalidades e
} 
Interessante observar que para fundamentar seu entendimento busca a lição de António Menezes Cordeiro que sustenta, em resposta a pergunta acima transcrita, que "o penhor de créditos tem por objecto não um direito - ou uma coisa - mas uma prestação.

Consequentemente não é direito real, nem penhor. A semelhança económica que apresenta com o penhor em sentido próprio justifica, contudo, que se fale em penhor de créditos(grifei)". ${ }^{12}$

Com a devida vênia, o referido autor na verdade defende que o chamado penhor de créditos sequer é penhor, e, portanto, não poderia ser um Direito Real. Apesar de haver uma afinidade de entendimentos, a premissa utilizada por António Menezes Cordeiro é diversa da de Luís Manuel Teles de Menezes Leitão. Para o primeiro não há penhor e, portanto, não há que se falar em Direitos Reais, para o segundo existe penhor, mas este não é Direito Real, mas sim obrigacional.

Em verdade, é notória a existência de uma certa anomalia na aplicação plena do instituto do penhor nestes casos, tanto mais porque a legislação luso-brasileira prevêm expressamente que em caso de lacunas e, no que couber, aplica-se ao penhor de direitos às regras do penhor de coisas, que é Direito Real.

A verdade é que as legislações luso-brasileira admitem o penhor de direitos, inclusive Orlando Gomes adverte que "o penhor não recai apenas em coisas, mas também, em direitos. Ao lado dos bens móveis corpóreos, podem ser gravados com ônus pignoratício os bens incorpóreos, a se aceitar esta classificação dos bens". ${ }^{13}$

Vaz Serra dá uma especial atenção ao penhor de direitos ${ }^{14}$, analisando com parâmetros mais precisos, o penhor de crédito que é o mais usual e conhecido dentro do tema. O que dá a condição de garantia ao crédito é o fato deste apresentar valor econômico, e, o tipo de garantia que mais se aproxima é o de penhor de direitos. Situação semelhante é o que ocorre no Direito Autoral.

Prova disto, é que Luís Manuel Teles de Menezes Leitão, na obra Direito de Autor, não levanta estas questões, apenas informa que este é modalidade especial do penhor de

\footnotetext{
atípicas. LEITÃO, Luís Manuel Teles de Menezes. Op. Cit., p. 20-22.

${ }^{12}$ António Menezes Cordeiro. Direitos Reais. Lisboa: Lex, 1979 , p. 754.

${ }^{13}$ GOMES, Orlando. Direitos Reais. $9^{a}$ ed. Rio de Janeiro: Forense, 1985, p. 354. Observe-se que a obra, apesar de anterior ao Código Civil de 2002, apresenta o tema atualizado, uma vez que não houve alterações de redação do texto legal em relação ao Código Civil de 1916, neste particular.

${ }^{14}$ Neste sentido veja a obra de VAZ SERRA, Adriano Paes da Silva. Penhor - Penhor de coisas - Penhor de direitos. Lisboa, 1956.
} 
direitos $^{15}$, o que demonstra a dificuldade do tratamento da matéria do penhor de direitos e, em especial, de garantias no Direito Autoral.

É evidente que se trata de tema que suscita muitas discussões doutrinárias, por ser difícil incluir um fato jurídico dentro de um instituto que não condiz exatamente com todas as suas características.

Daí porque, nestes casos o jurista deve ser mais pragmático, sem deixar de ser preciso quanto as críticas. Neste sentido é a lição de Adriano Vaz Serra: “o penhor sobre direitos é já hoje admitido entre nós. É discutida a sua natureza jurídica (se é direito sobre direito, se direito sobre a coisa que é objecto do direito empenhado). A questão não tem interesse prático e não cabe à lei decidi-la. Só importa a esta reconhecer que a vida exige o penhor de direitos e regulá-lo". 16

Ademais como destaca Antunes Varela "o penhor é concebido como o direito conferido ao credor de se pagar do seu crédito, com preferência sobre os demais credores, pelo valor de certa coisa móvel" ${ }^{17}$, sem qualquer reparo em relação a possibilidade de existência de penhor sobre coisas incorpóreas, como o penhor de direitos (e.g., créditos).

Vaz Serra igualmente adverte que "o penhor pode recair sobre coisas móveis ou sobre direitos(...). Atendendo às considerações feitas na exposição relativa às noções gerais sobre direitos reais de garantia, pode dizer-se que o penhor é um direito real de realização do valor de uma coisa móvel para garantia de um crédito" ${ }^{18}$ e, portanto tem eficácia erga omnes.

O penhor pode ser constituído por contrato, sendo uma garantia que traz como vantagem a preferência que o credor tem sobre os demais. Observe-se, mais uma vez que Vaz Serra deixa clara esta situação ao afirmar que "pelo penhor constitui-se, sobre uma coisa móvel (ou sobre um direito), a favor de um credor, para garantia do seu crédito, um direito real, que, entre outras vantagens, lhe confere preferência sobre os demais credores." 19

\footnotetext{
${ }^{15}$ Assim dispõe o autor: "O penhor do conteúdo patrimonial do direito de autor encontra-se previsto no art. $46^{\circ}$, constituindo uma modalidade especial do penhor de direitos, regulado nos arts. $679^{\circ}$ e ss. CC. Em consequência do penhor, o direito do credor pignoratício, em caso de execução, recairá especificamente sobre $\mathrm{o}$ dirieto ou direitos que o devedor tiver oferecido em garantia relativamente à obra ou obras indicadas (art. $46^{\circ}, n^{\circ} 2$ ), mas não são abrangidos pelo penhor os suportes materiais da obra (art. $\left.46^{\circ}, n^{\circ} 3\right)^{\prime \prime}$. LEITÃO, Luís Manuel Teles de Menezes. Direito Autoral. Coimbra: Almedina, 2011, p. 185.

${ }^{16}$ Ob. Cit., p. 5.

${ }^{17}$ Idem, p. 520.

${ }^{18}$ Ob. Cit., p. 5.

${ }^{19}$ Ob. Cit., p. 6.
} 
António Menezes Cordeiro destaca que "o penhor é um direito exclusivo das coisas móveis" e tem as seguintes qualidades: "deve ser certa ou determinada, não pode ser susceptível de hipoteca e tem de ser apta ao comércio privado". ${ }^{20}$

Constitui, portanto, elemento fulcral desta garantia real o fato desta recair sobre coisa móvel, incluindo nesta os direitos de créditos e todos os demais direitos de cunho patrimonial que não estão sujeitos ao regime da hipoteca, como observa Antunes Varela ${ }^{21}$.

Oportuno destacar que alguns bens móveis estarão sujeitos à hipoteca e não ao penhor, tendo em vista a natureza da constituição de seu direito que depende de registro ${ }^{22}$, como é o caso dos automóveis, das embarcações e aviões. Observar-se que a figura do registro da coisa não constitui elemento essencial para que esta garantia de constitua, o registro é condição para a existência da garantia.

Por isto importante a distinção feita por Antunes Varela no sentido de que "há no entanto, que distinguir sempre entre o objecto do direito e o objecto da garantia do direito" 23 . Esta observação serve não só para advertir que a forma de constituição de um direito sobre a coisa é diversa da forma de concretização da garantia sobre ela, bem como para reforçar as singularidades do penhor de coisas e do penhor de direitos, tão questionado.

Não se vai ater as questões dos diversos tipos de penhor, mas apenas àquele tipo que toca ao Direito Autoral, que, como se verá, é o penhor de direitos.

Vaz Serra de forma apropriada adverte que a matéria do penhor de direitos não "está muito completa" no Código Civil ${ }^{24}$, dando como norte o disposto no artigo $679^{\circ}$ que diz expressamente que as normas referentes ao penhor de coisas são aplicadas subsidiariamente ao penhor de direitos desde que não contrarie as disposições "relativas a este ou pela índole do mesmo penhor". 25

Retomando o entendimento de Vaz Serra, pode-se perceber que o tema exige uma solução dogmática e de ordem prática, o que se compartilha neste trabalho. Isto porque embora se sustente que a natureza jurídica do Direito Autoral é proprietária, tratado como um bem móvel, o fato é que não se pode deixar de observar que a obra, por ser imaterial e se

\footnotetext{
${ }^{20}$ Direitos Reais, p. 749..

${ }^{21}$ Ob. Cit., p. 510.

22 António Menezes Cordeiro ressalta que “o penhor só recai sobre coisas móveis não registráveis, essa publicidade tem de ser assegurada através da posse da coisa por parte do credor ou do terceiro, ou ainda na constituição de uma situação de composse". In Direitos Reais, p. 750. Oportuno destacar que somente se pode exercer posse sobre coisas corpóreas, móveis ou imóveis, motivo pelo qual não há que se falar em posse de coisas incorpóreas. $\mathrm{O}$ artigo $1302^{\circ}$ do Código Civil português é claro neste sentido.

${ }^{23}$ Idem, p. 539.

${ }^{24}$ Ob. Cit., p. 510 e ob. Cit., p. 537, respectivamente.

${ }^{25}$ Ob. Cit., p. 6.
} 
separar do seu suporte (material ou imaterial), não consegue alcançar todos os requisitos necessários para tanto, tais como a inexistência da posse, peculiaridade atribuída aos bens corpóreos.

No entanto o seu conteúdo patrimonial apresenta a característica da transmissibilidade, que é objeto do artigo $678^{\mathrm{a}}$ do Código Civil, razão pela qual a doutrina estuda o penhor de Direito Autoral na modalidade de direitos e, não no de coisas. Observando sempre, que há aplicação subsidiária das regras destas sobre aquelas no que couber.

No Brasil, o sistema é praticamente idêntico e também dispõe sobre o penhor de coisas e de direitos, além dos demais.

\section{1 - Penhor de direitos do conteúdo patrimonial autoral em Portugal}

O Código de Direito Autor e Direitos Conexos português disciplina a matéria no capítulo V, intitulado, "Transmissão e oneração do conteúdo patrimonial do Direito de Autor", nos artigos $40^{\circ}$ até $53^{\circ}$.

Oportuno advertir, que embora a tutela jurídica dos programas de computadores não esteja prevista no referido Código ${ }^{26}$, existe a aplicação subsidiária, como pequenas ressalvas no que diz respeito a não aplicação dos artigos $41^{\circ}$ a $43^{\circ}$ do Código de Direito de Autor e Direitos Conexos. Estes artigos referem-se ao regime de autorização, limites da transmissão e da oneração e transmissão ou oneração parciais.

No capítulo V do CDADC não existe uma uniformização do termo que se traduz em “conteúdo patrimonial” do Direito Autoral, pois são utilizadas diversas expressões que acabam por ter o mesmo significado. Mas apesar da "imprecisão terminológica" ${ }^{27}$ é possível deduzir que se está a falar das prerrogativas patrimoniais, com base na leitura e interpretação dos artigos $40^{\circ}$ a $53^{\circ}$. Da mesma forma que a lei não foi precisa no uso uniforme das palavras, utilizar-se-á aqui várias expressões.

\footnotetext{
${ }^{26} \mathrm{O}$ Decreto-Lei $\mathrm{n}^{\mathrm{o}} 252 / 94$ dispõe no artigo $1^{\circ} / 2$ que "Aos programas de computador que tiverem carácter criativo é atribuída protecção análoga à conferida às obras literárias" e o artigo $11^{\circ}$ prevê que "1 - Os negócios relativos a direitos sobre programas de computador são disciplinados pelas regras gerais dos contratos e pelas disposições dos contratos típicos em que se integram ou com que ofereçam maior analogia. 2 - São aplicáveis a estes negócios as disposições dos artigos $40 .^{\circ}, 45 .^{\circ}$ a $51 .^{\circ}$ e $55 .^{\circ}$ do Código do Direito de Autor e dos Direitos Conexos. 3 - As estipulações contratuais são sempre entendidas de maneira conforme à boa fé e com o âmbito justificado pelas finalidades do contrato". Para maiores detalhes da matéria ver VIEIRA, José Alberto C. A protecção dos programas de computador pelo Direito de Autor. Lisboa: Lex, 2005.

${ }^{27}$ Expressão utilizada por REBELLO, Luiz Francisco. Introdução ao Direito de Autor v. I. Lisboa: sociedade Portuguesa de Autores, Publicações Dom Quixote, 1994, p. 145.
} 
Na primeira parte do referido capítulo há previsão quanto às regras de transmissão das prerrogativas patrimoniais e na segunda às de oneração desta faculdade, tais como o usufruto, o penhor, o arresto e a penhora. A metodologia utilizada pelo legislador é pertinente, tendo em vista que se aplica à oneração, no que couber, as regras de transmissão das prerrogativas patrimoniais, pois como bem observa Luiz Francisco Rebello

as imposições, restrições, proibições e faculdades constantes dos artigos $42^{\circ}$, $43^{\circ}, 48^{\circ}$ e $49^{\circ}$ são comuns às duas figuras. Mas os artigos $45^{\circ}, 46^{\circ}, 47^{\circ}$ e $50^{\circ}$ contêm algumas disposições específicas acerca de determinadas formas de onerações de direito de autor: o usufruto, o penhor, o arresto e a penhora, das quais expressamente se diz que ele pode ser objecto. ${ }^{28}$

Como se pode perceber, o Direito Autoral admite o uso de figuras típicas dos Direitos Reais, em que pese haver na doutrina uma divergência acerca de sua natureza jurídica proprietária. José de Oliveira Ascensão, igualmente, faz esta observação, sem olvidar de afirmar que isto não implica a assunção destes como tais, e, explica que

ao formar-se o ramo do Direito de Autor, ainda por cima sob a égide da teoria da propriedade literária, artística e científica, os esquemas do Direito das Coisas foram naturalmente acolhidos. Passou a ver-se na formação de direitos derivados do direito de autor um desmembramento deste direito: uma parcela do conteúdo deste cindir-se-ia e passaria para o adquirente ${ }^{29}$.

A legislação portuguesa absorveu as regras dos Direitos Reais no Direito Autoral, seja por pragmatismo ou por convicção da natureza proprietária. O que importa é que dogmaticamente está a se falar de um bem móvel que está sob a égide de determinados tipos reais, incluindo, os de garantia.

Daí porque autores clássicos, citados por Vaz Serra ${ }^{30}$, já mencionavam a possibilidade do penhor de Direito Autor, dando inclusive contornos acerca da formalidade exigida para tanto, motivo pelo qual analisar-se-ão sucintamente as normas de transmissão do conteúdo

\footnotetext{
${ }^{28}$ Idem, p. 145.

${ }^{29}$ Idem, ibidem.

${ }^{30}$ A este respeito, em nota de rodapé $n^{\circ} 113$, Vaz Serra menciona:”ver, por exemplo, G. Moreira, $n^{\circ} 117,118$, 120; Paulo Cunha, Garantias, $n^{\circ} 141$. No nosso direito, o autor ou proprietário de uma obra literária ou artística pode dar em penhor os seus direitos (Decreto $\mathrm{n}^{\circ} 13.725$, de 3 de Junho de 1927, $\operatorname{art}^{\circ} 101^{\circ}$ ). No caso de penhor da propriedade intelectual, é necessário registo (Decreto cit., $\operatorname{art}^{\circ}, 105^{\circ}, \mathrm{n}^{\circ} 2$, e $106^{\circ}$ ). Sobre a propriedade industrial ver o Código. /113-a). Para Wolff, parágrafo $176^{\circ}$, I, o direito de penhor sobre um direito tem o mesmo caráter que o direito por le onerado: o direito de penhor sobre um crédito em si; um direito de penhor sobre uma acção é um direito de sócio; o que recai sobre uma patente é um direito sobre bens imateriais, etc.”. Ob. Cit., p. 509. Em que pese a lembrança destes autores, ainda é muito difícil encontrar na doutrina especializada um estudo aprofundado sobre as garantias no Direito Autoral, os autores que as mencionam são poucos e, via de regra não aprofundam a matéria.
} 
patrimonial do Direito Autoral, pois a forma e os requisitos do negócio autoral são aplicadas às onerações.

$\mathrm{O}$ artigo $42^{\circ}$ do $\mathrm{CDADC}^{31}$ deixa claro que não é possível haver transmissão ou oneração das prerrogativas morais do autor, dadas as características destas. O que é condizente com a teoria dualista do Direito Autoral adotada por Portugal.

Já os artigos $43^{\circ}$ e $44^{\circ}$ dispõe sobre a transmissão parcial e total do conteúdo patrimonial do Direito Autoral. O princípio basilar que rege a transmissão desta prerrogativa é a de que como existem várias modalidades de exploração econômica de uma obra, é possível que a transmissão e a oneração se dê por modalidades específicas ou em sua totalidade, dentro dos termos da lei.

$\mathrm{O}$ artigo $43^{\circ}$ do $\mathrm{CDADC}^{32}$, que fala sobre a transmissão e oneração parcial do conteúdo patrimonial do Direito Autoral, apresenta requisitos específicos para a validade deste contrato. Este deve ser escrito, com as assinaturas devidamente reconhecidas pelo notário, devendo constar obrigatoriamente o lugar, o tempo da utilização das modalidades específicas de utilização da obra, bem como o preço, se esta for onerosa. Se não houver uma estipulação de duração da transmissão ou da oneração por serem transitórias, a lei determina que o prazo máximo é de 25 anos, em geral, e 10 anos para as obras de arte aplicada e de fotografia. De qualquer forma ocorre a caducidade, se a obra, transmitida ou onerada parcialmente não for utilizada em 7 anos.

A transmissão ou oneração total do conteúdo patrimonial do Direito Autoral está prevista no artigo $44^{\circ}$ do CDADC. ${ }^{33}$ Sua admissibilidade exige maiores formalidades, tendo em vista que o autor e/ou titular de direito perde o controle patrimonial sobre a obra, em definitivo. Por isto a lei exige que o negócio seja feito por escritura pública que contenha o preço e a identificação da obra.

\footnotetext{
31 Artigo $42^{\circ}$ - Não podem ser objecto de transmissão nem oneração, voluntárias ou forçadas, os poderes concedidos para tutela dos direitos morais nem quaisquer outros excluídos por lei.

${ }^{32}$ Artigo $43^{\circ}$ - 1. A transmissão ou oneração parciais têm por mero objecto os modos de utilização designados no acto que as determina. 2. Os contratos que tenham por objecto a transmissão ou oneração parciais do direito de autor devem constar de documento escrito com reconhecimento notarial das assinaturas, sob pena de nulidade. 3 . No título devem determinar-se as faculdades que são objecto de disposição e as condições de exercício, designadamente quanto ao tempo e quanto ao lugar e, se o negócio for oneroso, quanto ao preço. 4. Se a transmissão ou oneração forem transitórias e não se tiver estabelecido duração, resume-se que a vigência máxima é de vinte e cinco anos em geral e de dez anos nos casos de obra fotográfica ou de arte aplicada. 5. O exclusivo outorgado caduca, porém, se, decorrido o prazo de sete anos, a obra não tiver sido utilizada.

${ }^{33}$ Artigo $44^{\circ}$ - A transmissão total e definitiva do conteúdo patrimonial do direito de autor só pode ser efectuada por escritura pública, com identificação da obra e indicação do preço respectivo, sob pena de nulidade".
} 
Estas regras são transportadas para o penhor do conteúdo patrimonial do Direito Autoral, no entanto, não indica a lei qual a modalidade de penhor a que está sujeito, se penhor de coisas ou de direitos. E é de suma importância esta determinação, porque no caso de incumprimento da obrigação garantida pela obra, as regras aplicadas são as constantes ao penhor do Código Civil.

$\mathrm{O}$ artigo $46^{\circ}$ do $\mathrm{CDADC}^{34}$ dispõe apenas que é possível dar o conteúdo patrimonial como garantia, qual seja, o penhor, que em caso de incumprimento, estará sujeito à execução que recairá sobre a obra (total) ou sobre as modalidades de uso (parcial) constantes no contrato e, que o credor pignoratício não adquire nenhum direito sobre o suporte material da obra $^{35}$.

A escassa doutrina aborda a matéria como sendo uma espécie de penhor de direitos, sem prestar maiores esclarecimentos. Mas se a própria legislação utiliza institutos típicos dos Direitos Reais, porque se fala em penhor de direitos e não em coisas?

A razão é simples, como não existe posse no Direito Autoral, não é possível ocorrer o desapossamento que, via de regra, é requisito necessário para o penhor de coisas, como se viu no item acima. Já o penhor de direitos tem como fundamento a possibilidade de transmissão do bem e publicidade da garantia realizada através do registro.

Ora, a propriedade autoral, no que diz respeito as prerrogativas patrimoniais, é suscetível de transmissão, desde que atendidas as formalidades previstas em lei, razão pela qual a modalidade do penhor de direitos é a que mais de adequa no Direito Autoral. A presente consideração é importante, porque mutatis mutantis, pode ocorrer a aplicação subsidiária das regras do penhor de coisas previstas no Código Civil.

Da pesquisa realizada pode-se dizer que apenas Luiz Francisco Rebello ${ }^{36}$ dedicou-se mais detalhadamente ao tema, embora timidamente. Assim, menciona que o penhor de Direito Autoral está sujeito às regras dos artigos $666^{\circ}$ a $685^{\circ}$ do Código Civil, sendo que aplica-se em

\footnotetext{
${ }^{34}$ Artigo $46^{\circ}$ - 1 . O conteúdo patrimonial do direito de autor pode ser dado em penhor. 2. Em caso de execução, recairá especificamente sobre o direito ou direitos que o devedor tiver oferecido em garantia relativamente à obra ou obras indicadas. 3 . O credor pignoratício não adquire quaisquer direitos quanto aos suportes materiais da obra.

${ }^{35} \mathrm{~A}$ distinção entre corpus mysticum e corpus mechanicum é fundamental no direito de autora, pois até pouco tempo atrás, antes da informatização, as obras estavam, via de regra dentro de um porte material, por exemplo um livro (corpus mechanicum - corpóreo) e a obra literária nela contida (corpus mysticum - incorpóreo). $\mathrm{Na}$ verdade a ressalva feita pela lei reforça o já disposto no artigo $10^{\circ}$ do CDADC, nos seguintes termos: "1. O direito de autor sobre a obra como coisa incorpórea é independente do direito de propriedade sobre as coisas materiais que sirvam de suporte à sua fixação ou comunicação. 2. O fabricante e o adquirente dos suportes referidos no número anterior não gozam de quaisquer poderes compreendidos no direito de autor".

${ }^{36}$ Ob.cit., p. 95.
} 
primeiro plano as normas relativas ao penhor de direitos, ou seja, as reguladas pelo artigo $679^{\circ}$ e seguintes.

Nos termos do artigo $215^{\circ}$ do $\operatorname{CDADC}^{37}$ o penhor do conteúdo patrimonial do autor está sujeito ao registro. Quando se tratar se penhor sobre modalidades de utilização do conteúdo patrimonial do autor a lei exige contrato escrito, com as assinaturas devidamente reconhecidas notarialmente, nos termos do artigo $43^{\circ} / 2$, já quando se tratar de penhor sobre a integralidade das prerrogativas patrimoniais é necessário a escritura pública nos termos do citado artigo $44^{\circ}$ do CDADC.

Se a obrigação não for cumprida e o credor tiver que se valer da garantia do Direito Autoral, a execução do penhor se dará nos termos dos artigos $675^{\circ}$ do Código Civil..$^{38}$

Como os artigos $1008^{\circ}$ a $1012^{\circ}$ do Código de Processo Civil, que tratavam sobre a venda e adjudicação do penhor foram revogados, o único dispositivo restante que poderia ser empregado no penhor de direitos autorais é o artigo $1013^{\circ}$ do Código de Processo Civil ${ }^{39}$.

Contudo este último apresenta uma situação de difícil superação prática, pois se trata da possibilidade da venda antecipada do penhor, o que não se coaduna perfeitamente dentro dos moldes do penhor de direitos, embora não exista óbice no uso do referido dispositivo.

Somente pode-se imaginar a ocorrência do referido dispositivo em caso de manifestos atos de má-fé do autor/devedor, tais como a tentativa da transferência total do conteúdo patrimonial a terceiro, onde o credor possui o penhor de uma modalidade de uso específico da obra, perdendo o credor, em princípio, a garantia. Trata-se de mero exemplo que como se pode constatar apresenta grandes dificuldades probatórias e possibilidades de empregos de

\footnotetext{
${ }^{37}$ Artigo $215^{\circ}$ - 1- Estão sujeito a registo: a) Os factos que importem constituição, transmissão, oneração, alienação, modificação ou extinção do direito de autor; b) $\mathrm{O}$ nome literário ou artístico; c) $\mathrm{O}$ título de obra ainda não publicada; d) A penhora e o arresto sobre o direito de autor; e) $\mathrm{O}$ mandato nos termos do artigo $74^{\circ}$. 2 - São igualmente objecto de registo: a) As acções que tenham por fim principal ou acessório a constituição, o reconhecimento, a modificação ou a extinção do direito de autor; b) As acções que tenham por fim principal ou acessório a reforma, a declaração de nulidade ou a anulação de um registo ou do seu cancelamento; c) As respectivas decisões finais, logo que transitem em julgado (grifei).

${ }^{38}$ Artigo $675^{\circ}-1$. Vencida a obrigação, adquire o credor o direito de se pagar pelo produto da venda executiva da coisa empenhada, podendo a venda ser feita extraprocessualmente, se as partes assim o tiverem convencionado. 2. É lícito aos interessados convencionar que a coisa empenhada seja adjudicada ao credor pelo valor que o tribunal fixar.

${ }^{39}$ Artigo $1013^{\circ}$ - 1. Se for requerida autorização para a venda antecipada, por fundado receio de perda ou deterioração da coisa empenhada, são citados para contestar, no prazo de 10 dias, o credor, o devedor e o dono da coisa, que não sejam requerentes, e em seguida o tribunal decidirá, precedendo as diligências convenientes. 2. Se for ordenado o depósito do preço, ficará esta à ordem do tribunal, para ser levantado depois de vencida a obrigação. 3. Enquanto a venda não for efectuada, o autor do penhor pode oferecer em substituição outra garantia real, cuja idoneidade será logo apreciada, suspendendo-se entretanto a venda..
} 
medidas judiciais acautelatórias para que a obra dada em garantia não passe para titular de direito diverso que constituiu o penhor.

Resta, por fim, questionar acerca da possibilidade do penhor sobre obras futuras, tendo em vista que, a rigor, o penhor não pode recair sobre coisas futuras. Como adverte Vaz $\mathrm{Serra}^{40}$, este pressupõe a entrega da coisa, e, se o penhor tem por objeto coisas futuras, a entrega é impossível. Mas aqui a regra é direcionada ao penhor de coisas e não de direitos, e é fato que no Direito Autoral, é viável a transmissão antecipada do conteúdo patrimonial do Direito Autoral, desde que atendidas determinadas condições.

$\mathrm{O}$ artigo $48^{\circ}$ do $\mathrm{CDADC}^{41}$ considera que a transmissão e a oneração das prerrogativas patrimoniais do autor sobre uma obra futura somente podem abranger àquelas que o autor vier a produzir dentro do prazo máximo de 10 anos, ainda que o contrato versar prazo superior. Se o prazo for superior a 10 anos, por exemplo 15 anos, a prazo será reduzido para 10 anos e o preço estipulado para 15 anos também será reduzido proporcionalmente a 10 anos. O que existe é a proibição de transmissão ou de oneração de obras futuras sem prazo contratual estipulado. Sendo assim, pode-se falar em penhor de direitos sobre o conteúdo patrimonial de obras futuras no Direito Autoral.

\section{2 - Penhor de direitos do conteúdo patrimonial autoral no Brasil}

O Direito brasileiro praticamente não fala sobre a possibilidade de garantia ou oneração no direito autoral, nem na lei autoral, nem no Código Civil, nem no Código de Processo Civil e nem mesmo nos projeto de reforma do CPC e no anteprojeto de Lei autoral.

Com esforço e pesquisa é possível vislumbrar que da mesma forma que a legislação portuguesa absorveu as regras dos Direitos Reais no Direito Autoral, o Brasil também o fez, basta rever a regra constante no inciso VIII do artigo 1.255 do Código Civil que considera o penhor como um Direito Real.

E, repete-se, não importa saber se foi por questões pragmáticas ou por convicção da natureza proprietária do Direito Autoral, o que vale é ter em mente que dogmaticamente se está a falar de um bem móvel sujeito a determinados tipos reais, incluindo, os de garantia.

\footnotetext{
${ }^{40}$ Ob. Cit., p. 59.

${ }^{41}$ Artigo $48^{\circ}$ - 1. A transmissão ou oneração do direito de autor sobre obra futura só pode abranger as que o autor vier a produzir no prazo máximo de dez anos. 2. Se o contrato visar obras produzidas em prazo mais dilatado, considerar-se-á reduzido aos limites do número anterior, diminuindo proporcionalmente a remuneração estipulada. 3. É nulo o contrato de transmissão de obras futuras sem prazo limitado.
} 
Embora não exista norma dispondo sobre a possibilidade do penhor do conteúdo patrimonial autoral no ordenamento brasileiro, ainda assim é possível encontrar fundamento para a sua ocorrência e utilização. Basta seguir as pistas dadas pela legislação portuguesa que não só admite esta garantia (penhor) como também a trata como espécie de penhor de direitos.

Pontes de Miranda, já no seu Tratado de Direito Privado, escrito sob a égide do Código Civil de 1916, que inicialmente continha dispositivos relativos a proteção do Direito Autoral, já preceituava a possibilidade do conteúdo patrimonial ser dado como garantia, na modalidade de penhor:

1. ADMISSIBILIDADE - O bem intelectual é suscetível de penhor. Tudo se passa à semelhança do penhor de bens corpóreos. A forma escrita é exigida. Tem-se de dizer, precisamente, o valor do débito e qual o bem incorpóreo, a obra, que se empenha. Em consequência, nada obsta a que o titular do direito de propriedade sobre o original (bem corpóreo) o empenhe e o titular do direito autoral de exploração (bem incorpóreo) o empenhe, a outrem, ou à mesma pessoa. Nem a que, sendo o mesmo o titular de um e de outro direito, os empenhe à mesma pessoa ou a pessoas diferentes. ${ }^{42}$

Rafael Menezes ao comentar o artigo 1.451 do Código Civil alerta que o penhor de direitos "incide sobre o direito autoral ou sobre um cheque ou uma nota promissória. Então o proprietário intelectual de obra autoral pode empenhá-la, afinal o direito do autor, embora incorpóreo, também integra o património das pessoas. E tudo o que é alienável é empenhável" ${ }^{43}$ Abrange o penhor de direitos não só o conteúdo patrimonial do autor, como também aqueles que foram considerados ativos intangíveis incorporados ao património da empresa.

Assim sendo, o artigo 1451 do Código Civil dispõe que "podem ser objeto de penhor direitos, suscetíveis de cessão, sobre coisas móveis". Ora as prerrogativas patrimoniais do Direito Autoral estão sujeitas à cessão, dentre outras modalidades de transferência, logo podem ser dados em garantia.

Além das disposições comuns à hipoteca e a anticrese, previstas nos artigos 1.419 a 1.430 do Código Civil, o penhor apresenta suas características e modalidades previstas nos artigos 1.431 a 1.472 .

\footnotetext{
${ }^{42}$ PONTES DE MIRANDA. Tratado de Direito Privado. \$ 1.895. penhor e \$ 1.896 Constringibilidade.

${ }^{43}$ MENEZES, Rafael. Penhor de Direitos. In: http://www.rafaeldemenezes.adv.br/reaiscoisa/aula14.htm, Capturado em 12.06.2012.
} 
Os artigos 1.451 a 1.460 do Código Civil dispõem sobre as regras a serem aplicadas no caso do penhor de direitos, no entanto, a maioria das normas estão direcionadas para os penhores de direitos de crédito e de títulos de crédito.

No que tange ao penhor do conteúdo patrimonial do Direito de Autor este é constituído através de instrumento público ou particular devidamente registrado no Cartório de Títulos e documentos, devendo o titular do direito empenhado entregar ao credor pignoratício os documentos comprobatórios deste direito, exceto se este tiver interesse legítimo em conservá-lo, nos termos do artigo 1.452 e parágrafo único do Código Civil ${ }^{44}$.

Aqui já é possível identificar uma das dificuldades do penhor no Direito Autoral: “entrega dos documentos comprobatórios”. Isto porque a proteção autoral se dá independente de qualquer registro ou formalidade, o que implica possibilidade da inexistência de tais documentos. E se, por cautela se fizer alguma espécie de registro que se configure num documento ele, por si só, não confere de forma absoluta a autoria e titularidade sobre a obra, mas isto será objeto de estudo posterior. Outro aspecto é que a lei civil não fala o que é “interesse legítimo", deixando assim uma margem para interpretação.

De qualquer forma vale lembrar a regra de, em caso de lacuna e no que couber, o penhor de direitos pode utilizar subsidiariamente dos dispositivos referentes ao penhor de coisas.

Feitas as considerações acerca da admissibilidade do penhor do conteúdo patrimonial do autor no ordenamento jurídico, é importante verificar sucintamente as regras de transmissão do conteúdo patrimonial do Direito Autoral, pois a forma e os requisitos do negócio autoral são aplicadas às onerações, tal como ocorre no direito luso.

Admite-se a transmissão total e parcial das prerrogativas patrimoniais do Direito Autoral, seja por cessão, licença, concessão ou outros meios admitidos pela Lei. As prerrogativas morais não são sucetíveis de transmissão. Quando se tratar de transmissão total, esta deve ser por escrito. No caso de não haver estipulação expressa a respeito do prazo de duração este valerá no máximo por 5 anos. Se não houver disposição em contrário a validade do contrato se dá apenas no território aonde o mesmo foi firmado. Quando se tratar de transmissão parcial, deve constar no contrato qual ou quais as modalidades de uso que estão sendo objeto da negociação. Em caso de silêncio presume-se que este foi firmado apenas para a modalidade essencial para o cumprimento da finalidade do contrato, de qualquer forma, não

\footnotetext{
${ }^{44}$ Art. 1.452. Constitui-se o penhor de direito mediante instrumento público ou particular, registrado no Registro de Títulos e Documentos. Parágrafo único. O titular de direito empenhado deverá entregar ao credor pignoratício os documentos comprobatórios desse direito, salvo se tiver interesse legítimo em conservá-los.
} 
pode existir estipulações para modalidades futuras, inexistentes à época do contrato, nos termos do artigo 49 da Lei 9.610/98. ${ }^{45}$

A cessão total ou parcial presume-se onerosa. Deve ser feita através de contrato escrito onde conste o seu objeto, tempo, ligar e preço, podendo ser averbado na margem do registro da Biblioteca Nacional, se a obra estiver registrada, ou, em não estando, deve ser realizado o registro no Cartório de Títulos e Documentos., nos termos do artigo 50 da Lei autoral. ${ }^{46}$.

Por fim é possível afirmar a admissibilidade do penhor do conteúdo patrimonial sobre obras futuras, desde que o prazo não ultrapasse 5 anos. Se no contrato constar prazo indeterminado ou superior, entende-se que prevalece o prazo legal de 5 anos, havendo a redução do prazo com a devida diminuição proporcional do preço, conforme dispõe o artigo 51 e parágrafo único. ${ }^{47}$

\section{2 - Dificuldades de se utilizar o penhor no Direito Autoral}

No item anterior já se pôde verificar que o penhor no Direito Autoral implica algumas dificuldades. Estas, por sua vez, são inquietações que estão presentes na abordagem feita pelos poucos doutrinadores que estudam a matéria. É o caso de Denis Borges Barbosa que já afirmava que "a utilização de bens como garantidores de obrigação tem problemas que se caracterizam por três aspectos: a) O bem é suscetível de garantia (penhor)? B) O bem é suscetível de execução (penhora)? C) Há uma estrutura de registro do ônus (penhor e penhora)?"

\footnotetext{
${ }^{45}$ Art. 49. Os direitos de autor poderão ser total ou parcialmente transferidos a terceiros, por ele ou por seus sucessores, a título universal ou singular, pessoalmente ou por meio de representantes com poderes especiais, por meio de licenciamento, concessão, cessão ou por outros meios admitidos em Direito, obedecidas as seguintes limitações:I - a transmissão total compreende todos os direitos de autor, salvo os de natureza moral e os expressamente excluídos por lei; II - somente se admitirá transmissão total e definitiva dos direitos mediante estipulação contratual escrita; III - na hipótese de não haver estipulação contratual escrita, o prazo máximo será de cinco anos; IV - a cessão será válida unicamente para o país em que se firmou o contrato, salvo estipulação em contrário; V - a cessão só se operará para modalidades de utilização já existentes à data do contrato; VI - não havendo especificações quanto à modalidade de utilização, o contrato será interpretado restritivamente, entendendo-se como limitada apenas a uma que seja aquela indispensável ao cumprimento da finalidade do contrato.

${ }^{46}$ Art. 50. A cessão total ou parcial dos direitos de autor, que se fará sempre por escrito, presume-se onerosa. § $1^{\circ}$ Poderá a cessão ser averbada à margem do registro a que se refere o art. 19 desta Lei, ou, não estando a obra registrada, poderá o instrumento ser registrado em Cartório de Títulos e Documentos. $\S 2^{\circ}$ Constarão do instrumento de cessão como elementos essenciais seu objeto e as condições de exercício do direito quanto a tempo, lugar e preço.

${ }^{47}$ Art. 51. A cessão dos direitos de autor sobre obras futuras abrangerá, no máximo, o período de cinco anos.Parágrafo único. O prazo será reduzido a cinco anos sempre que indeterminado ou superior, diminuindo-se, na devida proporção, o preço estipulado.
} 
Estas primeiras indagações, de certa forma, já foram respondidas ao longo do trabalho, mas é fundamental aprofundar algumas singularidades desta problemática, pois a garantia de uma obrigação só tem sentido se ela for forte o suficiente para evitar a necessidade de um reforço ou até mesmo uma alteração do bem que foi dado em garantia.

O penhor é uma garantia típica no Direito Autoral luso-brasileiro, mas o grande problema de dar o conteúdo patrimonial em garantia é a questão da posse, tendo em vista que uma das condições do penhor é o desapossamento.

Vaz Serra já mencionava que "a entrega é constituída pelo facto de dar ao credor a posse imediata do penhor, não bastando a posse mediata. Já aquela implica o desapossamento material do empenhador, indispensável para a publicidade do penhor e para a segurança do credor" 48

Desta forma, como destaca José de Oliveira Ascensão, a "perda da disponibilidade material da coisa dada em penhor" é que constitui seu elemento essencial, "esse elemento não é apenas um aspecto do facto constitutivo, é um verdadeiro elemento de existência, e portanto o penhor extingue-se quando ele cessa". ${ }^{49}$

Ora, o Direito Autoral, como em geral, a propriedade intelectual, é desprovida de posse, então como se falar em desapossamento nestes tipos de criações? Evidente que o legislador luso-brasileiro não está falando da perda da posse da obra, até porque no penhor de direitos o que se tem são documentos.

Resta saber de qual documento se está a falar no penhor do conteúdo patrimonial do autor, uma vez que a existência da obra independe de qualquer registro, formalidade e documento. A questão, então, resume-se em saber se é necessário formalizar o contrato nos termos das transmissões do direito autoral para que haja penhor?

Luís Manuel Teles Menezes de Leitão fala da possibilidade de penhor com ou sem desapossamento sendo interessante verificar que a perda da posse está atrelada situações onde a impossibilidade do uso do bem pelo devedor são dispensáveis em determinado período. ${ }^{50}$

Assim dispõe o autor acima citado que "essa especialidade de o penhor implicar a subtracção da posse da coisa ao seu titular leva a que este desempenhe uma função económica específica como garantia, sendo especialmente utilizada em bens de que o devedor não carece

\footnotetext{
${ }^{48}$ Ob. cit, p. 91.

${ }^{49}$ ASCENSÃO, José de Oliveira. Direito Civil - Reais. $5^{\circ}$ ed. Coimbra:Coimbra editora, 2012, p.552.

${ }^{50}$ Direitos Reais, p. 448.
} 
para fins comerciais ou industriais e que pode dispensar por um certo período, como bens de luxo, jóias e metais preciosos". 51

Observa-se assim que o penhor de coisas incide sobre bens cujo desapossamento não afetam o dia-a-dia do devedor, e, portanto nas outras espécies de penhor pode haver situações em que não há a perda da posse, até por disposição legal, como é o caso do Direito Autoral. A única exigência da lei é que ocorra a formalização, dentro dos termos da lei (escritura pública ou instrumento público ou privado, com assinaturas reconhecidas por via notarial) do penhor, tal como se exige para a transmissão do conteúdo patrimonial.

Neste sentido Luís Manuel Teles Menezes de Leitão pondera que "estão porém, contempladas legalmente situações especiais em que se verifica um penhor sem desapossamento" e cita como exemplo o caso especial do penhor mercantil, destacando que "para além deste caso especial encontram-se ainda previstas em lei especial certas modalidades particulares de penhor de direitos que dispensam o desapossamento, admitindo outras formas de publicidade, como por exemplo o registo. Estão nestas condições, designadamente o penhor de participações sociais (art. 23. ${ }^{\circ}, \mathrm{n}^{\circ} 3$ e $4 \mathrm{CSC}$ ), o penhor de valores mobiliários (art. $81 .^{\circ}$ e $103 .^{\circ} \mathrm{CVM}$ ) e o penhor de conteúdo patrimonial dos direitos de autor (art. 46. $.^{\circ} .^{\circ} 1$, CDADC e $215 .^{\circ}, n^{\circ} 1$ a) da Lei 45/85, de 7 de Setembro)"'(grifei). ${ }^{52}$

De qualquer forma, em não existindo o desapossamento o penhor se torna mais frágil, em especial quando se imagina a possibilidade de penhor de uma modalidade de uso do conteúdo patrimonial do autor, isto porque este titular permanece com a possibilidade de negociar ou até de onerar as outras modalidades existentes.

Talvez a maior dificuldade para dar em garantia um bem imaterial seja a estipulação correta do valor deste bem. Embora existam cálculos matemáticos para fazer esta apuração, a verdade é que no decurso do tempo entre a constituição da garantia e na execução da mesma, em caso de descumprimento, a obra pode ter valorizado ou depreciado.

Este aspecto, sem dúvida gera suspeitas e insegurança ao garantidor, muito mais que ao devedor, em especial se houver uma depreciação no valor. Obviamente que aqui se poderia evocar o princípio da autonomia da vontade, mas igualmente, conforme a situação, também se poderia invocar alterações supervenientes ao contrato. Há uma complexidade entorno deste problema.

\footnotetext{
${ }^{51}$ Direitos Reais, p. 448.

${ }^{52}$ Direitos Reais, p. 448-9. 
A própria possibilidade que a lei luso-brasileira confere de dar em penhor a totalidade ou modalidades de uso do conteúdo patrimonial é um entrave se o contrato não for bem delimitado. Ademais, como se sabe quem pode dar em garantia o conteúdo patrimonial do direito autoral é o titular de direito, que pode ser também o autor, ou não. Portanto, ressalvas relativas a quem é o autor, se este é o titular ou não é fundamental, os valores, a duração desta garantia devem estar expressos.

Quando o penhor se dá sob todo o conteúdo patrimonial não há maiores problemas, eis que se equipara a uma transferência total, a uma cessão total de direitos, mas quando se fala de modalidades os cuidados devem ser maiores, porque pode acabar existindo dois ou mais titulares de direito sob a mesma obra, mas para usos diversos. E isto pode enfraquecer a garantia dada. Veja que no Brasil o artigo 31 da lei $9.610 / 98^{53}$ vislumbra-se esta possibilidade, tal qual o faz o artigo $67^{\circ}$ e $68^{\circ}$ do Código de Direito de Autor e Direitos Conexos $^{54}$.

Em verdade pode-se falar numa garantia mais forte quando incide sobre a totalidade da criação intelectual, e, ainda assim pode estar sujeita a limitações advindas do exercício das prerrogativas morais do autor, que são intransferíveis e impenhoráveis.

Basta lembrar que na lei brasileira, no artigo $24^{55}$, existe a possibilidade do autor retirar a obra de circulação, arrepender-se, e a lei portuguesa, no artigo $62^{{ }^{556}}$ apresenta dispositivo semelhante. Então imagine-se a situação em que a obra foi dada em penhor e, de

${ }^{53}$ Art. 31. As diversas modalidades de utilização de obras literárias, artísticas ou científicas ou de fonogramas são independentes entre si, e a autorização concedida pelo autor, ou pelo produtor, respectivamente, não se estende a quaisquer das demais.

${ }^{54}$ Artigo " $67^{\circ}$ - Fruição e utilização 1 - O autor tem o direito exclusivo de fruir e utilizar a obra, no todo ou em parte, no que se compreendem, nomeadamente, as faculdades de a divulgar, publicar e explorar economicamente por qualquer forma, directa ou indirectamente, nos limites da lei. 2- A garantia das vantagens patrimoniais resultantes dessa exploração constitui, do ponto de vista económico, o objecto fundamental da protecção legal”. Artigo $68^{\circ}$ - formas de utilização 1 - A exploração e, em geral, a utilização da obra podem fazer-se, segundo a sua espécie e natureza, por qualquer dos modos actualmente conhecidos ou que de futuro o venham a ser. 2- Assiste ao autor, entre outros, o direito exclusivo de fazer ou autorizar, por si ou pelos seus representantes: (...) 3 - Pertence em exclusivo ao titular do direito de autor a faculdade de escolher livremente os processos e as condições de utilização e exploração da obra. 4 - as diversas formas de utilização da obra são independentes umas das outras e a adopção de qualquer delas pelo autor ou pessoa habilitada não prejudica a adopção das restantes pelo autor ou terceiros".

${ }^{55}$ Artigo 24 dispõe que: "são direitos morais do autor: (...) VI - o de retirar de circulação a obra ou de suspender qualquer forma de utilização já autorizada, quando a circulação ou utilização implicarem afronta à sua reputação e imagem. $\S 3^{\circ}$ Nos casos dos incisos V e VI, ressalvam-se as prévias indenizações a terceiros, quando couberem.

${ }^{56}$ Artigo $62^{\circ}$ que "O autor de obra divulgada poderá retirá-la a todo o tempo da circulação e fazer cessar a respectiva utilização, sejam quais forem as modalidades desta, contanto que tenha razões morais atendíveis, mas deverá indemnizar os interessados pelos prejuízos que a retirada lhes causar. 
repente, o autor se arrepende e faz valer o seu direito de arrependimento, como fica a garantia do credor?

Em ambos os casos a lei obriga indenizar ao titular, ou no caso, o credor pelos prejuízos causados, mas a apuração destes prejuízos implica mais prejuízos ao credor, de tempo e dinheiro, para além de descaracterizar o pragmatismo da existência de uma garantia.

O credor exige a garantia porque vê nela um meio fácil para obter a satisfação do seu crédito sem a necessidade de medidas executivas e judiciais, por outro lado o devedor dá em garantia um bem para evitar que o credor use medidas executivas e judiciais para buscar a satisfação do seu crédito no seu património, ao invés de ir diretamente ao bem indicado pelo devedor.

Para reforçar esta idéia, mesmo no plano da execução de uma obrigação, o Direito português consagrou o artigo $61^{\circ 57}$ que não deixa dúvidas quanto a intenção de preservar o direito moral do autor.

Ainda, para mencionar mais uma prerrogativa pessoal, no que diz respeito ao direito de modificação que decorre do direito à integridade da obra vale lembrar que no caso de transmissão da obra, quer por autorização, licença ou cessão, o direito de modificação da obra estará reservado ao autor por ocasião de uma nova edição desta.

Trata-se de um problema incontornável, pois o autor sempre pode se valer das prerrogativas morais e isto pode limitar o conteúdo patrimonial oferecido em garantia. A única opção é inserir previamente no contrato de penhor cláusula expressa que fixe um valor certo ou outro bem para o caso de eventual exercício das prerrogativas morais a título indenizatório.

Por fim, de todos os problemas acima apontados, pode-se dizer que o problema da certeza da autoria e integridade da obra são os mais complicados, porque a Lei autoral luso-

\footnotetext{
${ }^{57}$ Artigo $61^{\circ}$ - Direitos morais no caso de penhora 1 - Se o arrematante do direito de autor sobre obra penhorada e publicada promover a publicação desta, o direito de revisão das provas e correcção da obra e, em geral, os direitos morais não são afectados. 2- Se na hipótese prevista no número anterior, o autor retiver as provas sem justificação por prazo superior a 60 dias, a impressão poderá prosseguir sem a sua revisão". Lembrar que o artigo $50^{\circ}$ fala da possibilidade de se executar obras incompletas: "artigo $50^{\circ}$ - penhora e arresto de obra inédita ou incompleta 1 - Quando incompletos, são isentos de penhora e arresto, salvo oferecimento ou consentimento do autor, manuscritos inéditos esboços, desenhos, telas ou esculturas, tenham ou não assinatura. 2 - Se, porém, o autor tiver revelado por actos inequívocos o seu propósito de divulgar ou publicar os trabalhos referidos, pode o credor obter penhora ou arresto sobre o correspondente direito de autor".
} 
brasileira não exige para a proteção jurídica da obra e do autor qualquer espécie de formalidade.

Esta regra está presente em todos os países que são signatários da Convenção de Berna. No entanto, existe uma movimentação na Organização Mundial da Propriedade Intelectual em exigir o registro das obras, mas por enquanto segue a regra da informalidade.

Isto quer dizer que basta que o autor exteriorize a obra para que a tutela jurídica ocorra. Todo e qualquer registro feito com a obra é de caráter meramente declaratório, não constitui o direito, a autoria sempre pode ser questionada, bem como a integridade da obra. É o que dispõe a legislação luso brasileira ${ }^{58}$.

Este constitui um dos maiores entraves no que tange às garantias no Direito Autoral, diferente do que ocorre na seara da propriedade industrial, onde as marcas e patentes somente passam a ter guarida jurídica com o registro em órgão especial, que no caso brasileiro e português é no INPI - Instituto Nacional da Propriedade Industrial.

Assim, tanto as marcas como as patentes só serão consideradas como tais após o registro no INPI, o que não ocorre com o direito autoral. O registro na propriedade industrial é constitutivo do direito o que confere maior segurança quanto à autoria, titularidade e integridade da criação, o que não ocorre no Direito autoral onde estas questões podem ser sempre sucitadas. E mais, por estarem sujeitas ao registro, as limitações e ónus que recaiam sobre estas criações serão averbadas no registro.

É evidente que o contrato de transferência do conteúdo patrimonial do Direito Autoral deve ser registrado, mas isto não impede o questionamento quanto a autoria da obra. O registro tem a finalidade de publicizar perante terceiros a transmissão ou a oneração e nada mais.

Há, portanto, muitos senões quanto as garantias no Direito Autoral, mas estas dificuldades são apontadas com o objetivo de que haja uma especial atenção na forma da estipulação contratual da garantia, a fim de que ela possa ser considerada forte e segura, tal como uma garantia típica como o penhor de coisas ou uma hipoteca. Lembrando, sempre, que não há garantia isenta de problemas, porque a má-fé do devedor sempre pode estar presente seja numa garantia típica ou atípica, o mesmo se passando numa garantia no Direito Autoral, como o penhor.

\footnotetext{
${ }^{58}$ Em Portugal está expresso no artigo $12^{\circ}$ - reconhecimento do direito de autor. O direito de autor é reconhecido independentemente de registo, depósito ou qualquer outra formalidade". Já no Brasil "Artigo 18. A proteção aos direitos de que trata esta Lei independe de registro; e, Artigo 19. É facultado ao autor registrar a sua obra no órgão público definido no caput e no $§ 1^{\circ}$ do art. 17 da Lei $n^{\circ} 5.988$, de 14 de dezembro de 1973 ”.
} 


\section{CONSIDERAÇÕES FINAIS}

O presente trabalho não almejou esgotar o estudo do penhor no Direito Autoral, mas sim, desvendá-lo através da análise comparada no ordenamento jurídico luso-brasileiro. No entanto algumas ponderações podem ser feitas, o que contribuirá para eventual aprofundamento da matéria no futuro.

O Direito Autoral é um direito que apresenta duas facetas, uma de ordem moral e outra de ordem patrimonial, e, embora seja obrigatório preservar seu aspecto pessoal, o segundo é transmissível e apresenta valor económico, estando, portanto, sujeito às garantias.

A valorização econômica dos bens imateriais vem sendo observada no mercado mundial, razão pela qual muitas empresas inserem no seu balancete como ativo intangível o valor das criações imateriais. Além de tornar a empresa economicamente atrativa, possibilita dar em garantia estes ativos para ampliar e expandir os seus negócios.

Entretanto quando se está a falar em garantias há que se ter em mente que elas podem ser típicas ou atípicas. Dentro do rol das garantias reais típicas luso-brasileira, o Direito Português contempla expressamente como no Código de Direito de Autor e Direitos Conexos o penhor de direitos e no Código Civil os privilégios creditícios. Já a Lei Autoral brasileira não previu qualquer espécie de garantia, mas do estudo do Código Civil pode-se afirmar que é possível que o conteúdo patrimonial autoral está sujeito ao penhor, bem como existe um dispositivo acerca da incidência de privilégios creditórios no Direito Autoral.

A incidência de garantias no Direito Autoral é incontestável, porém, também pode-se dizer o mesmo quanto a existência de inúmeras dificuldades na sua implementação e exigência em caso de incumprimento do negócio jurídico garantido.

Dentre as dificuldades que se encontraram pode-se citar as relacionadas a posse da obra, o valor económico da obra dada em garantia ou de suas modalidades, as limitações e o enfraquecimento da garantia em eventual arguição de uma prerrogativa moral do autor, para além das questões de inexistência de formalidade que atestem a autoria e integridade da obra.

É importante ter em mente que tanto o autor como o titular derivado podem dar em garantia o conteúdo patrimonial do Direito Autoral, pois quando o autor cede (transmite) para terceiros a obra ou modalidades de sua utilização, é o terceiro que tem o poder de dar em garantia a criação ou contrato autoral, permanecendo o autor com as faculdades morais. 
Porém as prerrogativas morais e patrimoniais não podem ter uma separação tão absoluta, tanto é verdade que o exercício de determinadas faculdades morais, como o direito de retirada da obra pode afetar o aspecto económico de quem detém o exercício exclusivo de exploração econômica e, portanto, pode atingir a própria garantia. Talvez em razão disto seja tão difícil encontrar casos de garantias no Direito Autoral, já quando se fala propriedade industrial esta já é mais bem aceita entre os credores, como e.g., os Bancos.

Daí poder ser considerada uma garantia "fraca" frente a outras que o credor poderia utilizar. Entretanto o conteúdo patrimonial do autor, dentro da economia do conhecimento, tem elevado valor económico, as indústrias culturais (fonográfica, cinematográfica, software, televisiva, editorial, etc.) possuem ativos, administram acervos e contratos autorais de grande porte o que gera uma segurança no mercado financeiro. Nestes casos, as garantias no Direito Autoral não podem ser entendidas como frágeis, pois decorrem de situações jurídicas seguras, o mesmo podendo-se dizer dos autores, enquanto pessoas físicas, que dão em garantia contratos de transmissão do Direito Autoral.

Em verdade, não se conclui, pois há muitas sutilezas a serem estudadas nesta temática, sendo o presente trabalho apenas a "ponta do iceberg" para utilizar uma expressão coloquial. A escassa doutrina e jurisprudência não facilita a atividade do investigador, porém, espera-se ter contribuído um pouco para o debate e aprofundamento da matéria.

\section{REFERÊNCIAS BIBLIOGRÁFICAS}

ABRANTES, José João. Contratos da propriedade intelectual e contrato de trabalho. In: Contratos de direito de Autor e de Direito Industrial. ALMEIDA, Carlos Ferreira de, GONÇALVES, Luís Couto et TRABUCO, Cláudia (organizadores). Coimbra: Almedina, 2011, p. 79-91.

ALVES, Hugo Ramos. Do penhor. Coimbra: Almedina, 2010.

ASCARELLI, Tulio. Teoria della concurrenza e dei beni imateriali. Milano: Giufrè, 1958. ASCEnSÃO, José de Oliveira. Direito Civil - Direito de Autor e Direitos Conexos. Reimpressão. Coimbra:Coimbra editora, 2008.

ASCENSÃO, José de Oliveira. Direito Civil - Reais. $5^{\text {a }}$ ed. Coimbra:Coimbra editora, 2012. BARBOSA, Denis Borges. Uma Introdução à Propriedade Intelectual. $2^{\mathrm{a}}$ ed., Rio de Janeiro: LumenJuris, 2003. 
COSTA, Adalberto. Apresentação em slides sobre direito da propriedade intelectual. In: http://www.regisconsultorum.pt/autor.html, capturado em 16/06/2012.

DUARTE, Rui Pinto. Curso de Direitos Reais. Cascais: Principia. 2002.

GOMES, Manuel Januário da Costa. Assunção fidejussória de dívida - sobre o sentido e o âmbito da vinculação como fiador. Coimbra: Almedina, 2000.

GOMES, Orlando. Direitos Reais. 9ª ed. Rio de Janeiro: Forense, 1985.

LEITÃO, Luís Manuel Teles de Menezes. Garantia das obrigações. $3^{\mathrm{a}}$ ed. Coimbra: Almedina, 2012.

LEITÃO, Luís Manuel Teles de Menezes. Direitos Reais. Coimbra: Almedina, 2009.

LEITÃO, Luís Manuel Teles de Menezes. Direito de Autor. Coimbra: Almedina, 2011.

MARTINEZ, Pedro Romano et PONTE, Pedro Fuzeta da. Garantias de cumprimento. $5^{\text {a }}$ ED. Coimbra: Almedina, 2006.

MENDES, Adriano Dias e BRAGA, João Paulo Carneiro de H. BNDES - ativos intangíveis (http://www.bndes.gov.br/SiteBNDES/export/sites/default/bndes_pt/Galerias/Arquivos/conhe cimento/livro_brasil_em_transicao/Brasil_em_transicao_cap09.pdf). Acessado em 15 de Junho de 2012.

MENEZES CORDEIRO, António. Direitos Reais. Lisboa: Lex, 1979.

MENEZES CORDEIRO, António. Tratado de Direito Civil Português, $2^{\circ}$ v.: Direito das Obrigações, $4^{o}$ t.: cumprimento e não cumprimento, transmissão, modificação e extinção, garantias. Coimbra: Almedina, 2010.

MENEZES, Elisângela Dias. Curso de Direito Autoral. Belo Horizonte: DelRey, 2007.

MENEZES, Rafael. Penhor de Direitos. In: http://www.rafaeldemenezes.adv.br/reaiscoisa/aula14.htm, Capturado em 12.06.2012.

PEREIRA, Alexandre Dias. Informática, Direito de Autor Propriedade Tecnodigital. Coimbra: Ed. Coimbra, 2001.

REBELLO, Luiz Francisco. Código do direito de autor e dos direitos conexos - anotado legislação complementar e convenções internacionais. Lisboa: Livraria Petrony, 1985.

REBELLO, Luiz Francisco. Introdução ao Direito de Autor. V. I. Lisboa: sociedade Portuguesa de Autores, Publicações Dom Quixote, 1994.

KALANJE, Christopher. Role of IP in raising finance. In: http://www.wipo.org/sme/en/activies/meetings/wipo_wasme_03/presentation/wipo_wasme_ip r_ge_03_17pdf . Capturado em 02.05.2012. 
VASCONCELOS, Pedro Pais de. Contratos Atípicos. $2^{\text {a }}$ ed. Coimbra: Almedina, 2009

VAZ SERRA, Adriano Paes da Silva. Penhor - Penhor de coisas - Penhor de direitos. Lisboa, 1956.

VARELA, João de Matos Antunes. Das obrigações em geral. 2 ed. Coimbra: Almedina, 1992.

VIEIRA, José Alberto C. A protecção dos programas de computador pelo Direito de Autor. Lisboa: Lex, 2005.

Publicado no dia 27/02/2013

Recebido no dia 01/12/2012

Aprovado no dia 06/01/2013 